TEME, г. XLIV, бр. 1, јануар - март 2020, стр. 65-81

\begin{tabular}{lr}
\hline \hline Оригинални научни рад & https://doi.org/10.22190/TEME191205009V \\
Примљено: 5. 12. 2019. & UDK 347.27 \\
Ревидирана верзија: 10. 2. 2020. & 347.447 \\
Одобрено за штампу: 20. 2. 2020. &
\end{tabular}

\title{
MORTGAGOR'S LIABILITY FOR THE PRESERVATION OF THE VALUE OF A MORTGAGED REAL ESTATE ${ }^{a}$
}

\author{
Milica Vučković, Miroslav Lazić \\ University of Niš, Faculty of Law, Niš, Serbia \\ milica@prafak.ni.ac.rs
}

\begin{abstract}
In this paper, the authors analyze the civil law liability of a mortgage debtor (mortgagor) in cases where the debtor breaches the obligation of treating the mortgaged real estate in compliance with the legal standard of acting with due diligence of "a good host" or "a good businessman," and thus depreciates its value to the extent that jeopardizes the possibility of enforcing the claim. Given the accessory nature of mortgage which is aimed at securing the claim as the primary right, this form of civil liability and the corresponding rights of the mortgage creditor (mortgagee) are applicable before raising the issue of traditional civil law liability, which implies the maturity of the receivables and compensation for the damage sustained by the creditor. This form of civil liability may also be used preventively when there is a real risk of causing damage to the mortgagee. The relationship between civil law liability and the insurance of the mortgaged asset implies that they do not exclude but complement each other.
\end{abstract}

Key words: civil liability, mortgage, depreciation of real estate value, value preservation, insurance.

\section{ОДГОВОРНОСТ ХИПОТЕКАРНОГ ДУЖНИКА ЗА ОЧУВАҢЕ ВРЕДНОСТИ ЗАЛОЖЕНЕ НЕПОКРЕТНОСТИ}

\begin{abstract}
Апстракт
У раду анализирамо грађанскоправну одговорност хипотекарног дужника у случају када прекрши обавезу поступања са заложеном ствари по правном стандарду „добар домаћин”, односно „добар привредник”, и умањи њену вредност у мери да угрози могућност намирења потраживања. Пошто је хипотека акцесорне природе и у функцији је обезбеђивања потраживања као главног права, ова одговорност и одговарајућа права за хипотекарног повериоца делују пре наступања класичне грађанскоправне одговорности (која подразумева доспелост потраживања и штету за
\end{abstract}

\footnotetext{
${ }^{a}$ Рад је резултат истраживања на пројекту Усклађивање права Србије са правом Европске уније, који финансира Правни факултет Универзитета у Нишу.
} 
повериоца). Она се може користити и превентивно, када постоји реална опасност наступања штете за хипотекарног повериоца. Однос грађанскоправне одговорности и осигурања заложене ствари указује на то да се оне не искључују, већ допуњују.

Кључне речи: одговорност, хипотека, очување вредности, умањење вредности предмета хипотеке, осигурање.

\section{INTRODUCTION}

The contemporary legal system has been adapting to the modern lifestyle which is fraught with ample risks, leading to frequent violations against natural persons and their property in various social relations. Such circumstances call for the establishing of the new forms of liability in civil law, as well as in criminal law, misdemeanour law and administrative law. In the $20^{\text {th }}$ century, the legal response to the constant expansion of different types of liability was the acceptance of objective liability, i.e. strict liability regardless of fault. It was followed by the expansion of preventive liability.

The application of property-related sanctions to diverse legal relations, ranging from the protection of property rights to the protection of personal (non-property) rights, has been expanding. Protocol No. 4 to the European Convention on Human Rights (ECHR) ${ }^{1}$ obliges the signatory states to envisage property-related sanctions as the only ones applicable in civil law relations ${ }^{2}$. The classification of sanctions into preventive and reparative is particularly important. Reparative sanctions include "the instruments of direct coercion, the instruments of indirect coercion, and reparations according to the equivalence principle [...] Civil law sanctions, imposed on such grounds, should enable that personal goods and/or property of a specific person are restored to the position they would most likely have had if they had not been endangered or damaged. In effect, these sanctions aim to ensure resitutio in integrum" (Nikolić, 1995: 98).

Changes in the legal entities' assets "may be a consequence of many various facts, some created by the stakeholders' will, most frequently manifested in the form of a contract, but some of them emerged independently of their will or even contrary to it" (Simonović, 2013: 106). However, civil law liability cannot be limited only to tort law or only to the reactive protection after the violation. Preventive protection has been increasingly expanding as well. Preventive actions are primarily aimed at eliminating the risk of the occurrence of damage. Civil law liability also

\footnotetext{
${ }^{1}$ Protocol No. 4 to the Convention for the Protection of Human Rights and Fundamental Freedoms, securing certain rights and freedoms other than those already included in the Convention and in the first Protocol thereto, ETS No.046, Strasbourg, 16/09/1963; https://www.echr.coe.int/Documents/Library_Collection_P4postP11_ETS046E_ENG.pdf ${ }^{2}$ Protocol No. 4 (Article 1) provides that "No one shall be deprived of his liberty merely on the ground of inability to fulfil a contractual obligation."
} 
includes diverse forms of protection of parties against non-performance of any contractual or statutory obligation.

In addition to liability for damage, the application of additional security instruments has also been expanding, such as personal ${ }^{3}$ and real ${ }^{4}$ securities (including mortgage), which supplement the debtor's propertyrelated liability "by increasing the likelihood that the creditor will really satisfy his claim" (Medić, 2013: 7). The liability for the preservation of a mortgaged real estate value is an attempt of preventive assurance of propertyrelated sanctions enforcement.

The topic of this paper is the mortgagor's liability for the preservation of the mortgaged realty value from the moment the mortgage is established to the moment it is extinguished. We analyse property-related liability as a specific substantive law relation in the context of mortgage which is used as an accessory instrument for the purpose of securing a claim. In order to analyse this aspect of liability, we first deal with the general civil law liability issues which have to be taken into account in considering the specific position of the owner of mortgaged realty, who is in the position of a mortgagor (debtor), and his liability for the preservation of the mortgaged realty value. However, prior to pursuing the traditional property-related liability of the mortgagor for the non-performance of his obligation, the mortgagee (creditor) has at his disposal the security instruments which are aimed at the mortgaged asset in possession of the mortgagor (debtor).

\section{THE CONCEPT AND TYPES OF LIABILITIES}

In general, legal liability is a consequence of unlawful conduct. Thus, depending on the type of the violated legal norm, there are criminal, administrative and civil delicts, and the corresponding liabilities thereof. The common characteristics of legal liability are described as follows: "they are sanctions for the violation of law; they contain social condemnation of the responsible person's conduct, and they are manifested in certain negative consequences for the responsible person" (Radišić, 2014: 198,199).

Pursuant to the Obligations Act ${ }^{5}$, "Parties to an obligation relationship shall be bound to carry out their obligations and shall be responsible for the

\footnotetext{
${ }^{3}$ For instance, a joint and several warranty is a personal collateral, which essentially entails multiplying the debtors, i.e. the properties of two persons: the debtor and the warrantor, from which the property-related sanction can be enforced.

${ }^{4}$ Beside property-related sanctions, the debtor or a third person pledges a specific object from which the mortgagee (creditor) can be satisfied.

${ }^{5}$ Zakon o obligacionim odnosima [Obligation Relations Act, 1978], Službeni list SFRJ, br. 29/78, 39/85, 45/89; available at https://www.mpravde.gov.rs/files/The\%20Law\%20of\% 20Contract\%20and\%20Torts_180411.pdf
} 
performance thereof" (Art. 17). "The liability comes to the fore only if the debt has not been voluntarily paid, if it is collected with the assistance of state enforcement bodies" (Radišić, 2014: 34). However, such an obligation is present in any legal relationship in real property, succession and family law. Therefore, property-related sanctions, with some adjustments in the form of natural and monetary restitution, are suitable for all legal relationships. If the titleholder of obligation (debtor, mortgagor, etc.) does not perform their obligation voluntarily, the legal order offers specific enforcement instruments to the titleholder of the rights (owner, creditor, mortgagee, etc.).

Depending on the legal ground it rests upon, civil liability is basically classified into contractual and non-contractual liability. Contractual liability is based on the breach of contractual or statutory obligations within a legal relationship which has been created before the damage occurs. Noncontractual liability arises at the moment of causing damage in situations that do not involve a special legal relationship between the tortfeasor and the injured party (the person who sustained damage), due to the violation of the general ban not to cause harm to another (neminem laedere) (Radišić, 2014: 201, 202).

Although liability is a typical feature of obligation relations, it is a much broader category. "The problem of liability has become an issue of primary, theoretical, and practical importance; it is the first and foremost point of the civil law, constantly gaining ever increasing significance worldwide. However, apart from being constantly developed and reinforced, liability increasingly encompasses new legal relations; it arises from various sources in diverse aspects of life, in all legal areas; [...] liability has evolved in both quantitative and qualitative terms [...]" (Josserand, 1992: 1164, 1165). In contemporary civil law, the expansion of subjective liability has led to establishing objective liability regardless of fault (culpa). "The demand for citizens safety constitutes a relevant legal policy motif for introducing and increasing the number of special laws (lex specialis) which envisage the so-called objective liability regardless of fault (strict liability) for specific types of damage in tort law" (Stojanović, 1992: 1188).

Preventive protection has also been expanding for the sake of damage prevention, where an application for the elimination of danger/risk can be filed only when there is imminent danger of the occurrence of damage. "The legal ground for liability of a holder of any source of danger lies at the very danger of an occurrence of significant damage; therefore, it is an obligation lawsuit... Besides, under the Obligations Act (Art. 156), one is held liable for the presence of risk of causing more substantial damage (not for the actual damage that has occurred); thus, it provides for the exercise of the preventive function in law and precludes the occurrence of great damage" (Kovačević Kuštrimović, 1992:1238).

Property-related sanctions are characteristic for all types of civil law relations in contract law, tort law, real estate law, succession law, etc. 
Bearing in mind the position of the owner of the mortgaged asset, we are interested in the damage that virtually occurs to the mortgage creditor (mortgagee) due to the diminished value of the mortgaged estate. This damage may occur through commission, omission to act, or the possible abuse of ownership or other property rights by breaching a contractual or statutory obligation. Under the general liability rules, the mortgagee may invoke contractual liability for damages only after the maturity of the claim. However, beforehand, they are availed legal instruments that they have received on the grounds of mortgage as a real security. These instruments are the subject of analysis hereinafter.

Therefore, the mortgagor's liability is the consequence of inobservance of the statutory and (most frequently) contractual obligation of safeguarding the mortgaged asset. The statement that "the claim for damages referred to in the contract is due for payment at the moment when the performance of obligation was about to ensue, and even where the impossibility of its performance has occurred earlier" (Radišić, 2014: 205) is not valid because it does not entail a traditional claim for damages, but preventive civil liability resting on mortgage. Civil law sanctions based on mortgage have an immediate preventive effect, irrespective of the maturity of claim.

\section{THE LEGAL POSITION OF A MORTGAGEE AND A MORTGAGOR REGARDING THE PRESERVATION OF THE MORTGAGED REAL ESTATE VALUE}

A mortgage is a security interest on an immovable property. Beside ensuring the debtor's property-related liability, it additionally secures the creditor in the event that the debtor does not pay the debt upon the maturity of claim, by providing the possibility to collect the claim by selling the mortgaged asset. The mortgage is operative in the sphere of liability; at first, it exists as a possibility ("latently, potentially"), and it may only be activated if this "psychological" pressure of the mortgage remains ineffective and the maturity of the claim and the debtor's default take place (Stojanović, Pop-Georgiev, 1989: 232). Therefore, in legal theory, the mortgagee's authorisations are clearly distinguished in two phases designated as the "security phase and settlement phase" (Hiber, Živković, 2015: 249).

The function of the security phase is to "preserve" the value of the mortgaged asset and protect it from possible risks that may jeopardise the future enforcement of the mortgagee's claim. In this phase, before the enforcement right has taken place, the mortgagor/debtor's liability to 
preserve the value of the mortgaged asset and the corresponding ${ }^{6}$ rights of the mortgagee (creditor) is the most important. Although this phase seems to be "static", mortgage may take effect within this phase owing to the debtor's liability to manage the property with due diligence.

In the settlement phase, the sale of the mortgaged asset and the collection of the claim take place. Thereby, the psychological pressure of the mortgage becomes a reality (in cauda venenum). After the maturity of the claim and the debtor's default, the mortgagee (creditor) may opt for one of the two available legal actions for the enforcement of their claim: to file a lawsuit under the law of obligations for the compensation from the debtor's property and/or to file a lawsuit under real property law for the compensation from the mortgaged asset. The mortgagee may also file both actions, either simultaneously or one after another, if they cannot fully satisfy their claim on the basis of one; these options are provided in view of the fact that the stated grounds are not contradictory and mutually exclusive (Capelle, 1963: 101; Soergel and Siebert, 1968: § 1147). ${ }^{7}$

For the mortgagor (debtor), the mortgage implies a restriction to property and primarily creates specific obligations. For the mortgagee (creditor), the mortgage is predominantly manifested as a set of rights, mutually conditioned and aimed at achieving the same goal - the preservation of the mortgaged property value and the right to enforce the claim. However, given the fact that it is an accessory right, the mortgage cannot be viewed on its own, but only in conjunction with the claim it secures. The true purpose of individual authorisations and obligations can be seen only when considered in such a way. The legal position of the mortgage parties in terms of preserving the mortgaged asset value depends on the mortgagor's duties and the corresponding rights of the mortgagee.

\footnotetext{
${ }^{6}$ Although there is no full correlation between these real property law authorisations and obligations which is apparent in the law of obligations (contracts and torts), some of these authorisations and obligations are most approximate to real property relation, considering that they are regulated by the law and aimed at accomplishing the same goal - the preservation of the mortgaged asset value. It is common knowledge that, in the so-called iura in re aliena, there are two parties within a legal relationship, with authorisations and obligations which are correlated in a similar manner as obligation rights (e.g. the right to access and the obligation to enable access to the mortgaged asset), whereas third persons have an obligation to refrain from violating the real right.

${ }^{7}$ In the Serbian law, the mortgagee may request that their mature claim is satisfied as follows: 1) first, from the mortgaged real estate value and, then, from the debtor's remaining property; 2) simultaneously from the mortgaged real estate value and from the debtor's property; or 3) first from the debtor's property and only after that from the mortgaged real estate value (Art. 25, Mortgage Act). Zakon o hipoteci [Mortgage Act, 2005], Službeni glasnik RS, br. 115/2005, 60/2015, 63/2015, 83/2015.
} 


\subsection{Mortgagor's Obligations}

No property authorisation of the owner of a mortgaged property is fully absorbed by the establishment of a mortgage, but some of them are restricted. The mortgagor keeps all the attributes of ownership over the mortgaged asset (to hold the object; to use it; to collect and enjoy the fruits thereof; to sell, lease, pledge it, etc.); in principle, for undertaking such legal actions, they do not need the consent of the mortgagee as their rights are not restricted (Art. 16, Mortgage Act) ${ }^{8}$. Therefore, the owner of the mortgaged property is encumbered by a set of obligations which restrict some of these authorisations. The basic obligations of the mortgagor in terms of preserving the mortgaged property value are as follows:

2.1.1. The owner of mortgaged real estate may not make any physical changes in the object of mortgage without the creditor's written consent (Art. 17, Mortgage Act). This means that the owner cannot perform any works that change the factual state of the real estate (e.g. making partition-walls, making additions, demolition, joining, partition, etc.). The mortgagee may refuse to grant their written consent for such works on reasonable grounds only, i.e. if there is any danger that the value of the mortgaged asset will be reduced thereby. In case of a dispute, it would be subject to judicial determination, on the basis of findings of an expert of adequate profession. We deem that these rules are accordingly applied in the event where the debtor wants to change the purpose of that object.

2.1.2. The owner shall look after and maintain the object of mortgage as expected of a good host (natural persons) or a good businessman (legal persons). This obligation aims to avoid the depreciation of the real estate due to the owner's actions or omissions to act (Art. 17, para. 1 and 2, Mortgage Act). This duty is not considered to be "difficult" to perform as it is in the owner's interest ${ }^{9}$, and it exists whether or not the owner or a third person is the direct holder of the mortgaged asset.

\footnotetext{
${ }^{8}$ In contrast, the Act on the Right of Pledge on Movable Property and rights registered in the Pledge Registry (art. 24) permits that the pledge agreement may exclude the right of the pledgor to dispose of the object of pledged right. This possibility is justifiable because the provision refers to a movable asset which, as a matter of fact, may be more difficult to track than real estate. Zakon o založnom pravu na pokretnim stvarima i pravima upisanim $\mathrm{u}$ registar [Act on the Right of Pledge on Movable Property registered in the Pledge Registry, 2003], Službeni glasnik RS, br. 57/2003, 61/2005, 64/2006, 99/2011.

${ }^{9}$ Such treatment of the asset is expected of any owner as it is in their own interest, but after the establishment of mortgage such behaviour is their duty. They must refrain from any actions representing a non-economical and irrational treatment of the mortgaged object, which they would have been entitled to as the owner even if there was no mortgage.
} 
The depreciation of the mortgage property value may be performed by means of a legal action or factual conduct of the mortgagor, or a holder of the mortgaged property. Such a value depreciation by means of a legal action would occur in cases where the establishment of some permanent right would reduce the mortgaged object value at the moment of the maturity of claim (e.g. real easements on the mortgaged object as a servient estate or urban land consolidation (Lazić, 2017b:365). However, the creditor is also protected from legal actions by the right of priority; thus, any subsequently established right has no priority. Therefore, this priority protection is primarily intended for the control of factual actions of the holder against the object of mortgage. The depreciation of value by a factual action of the holder is possible, for example, by omitting to prune or over-pruning grapevines in vineyards, failing to maintain the rooftop structure, and alike. It is not required that the depreciation of value is caused by the owner, but it is enough that there is a casual link between the debtor's action and the depreciation of value. ${ }^{10}$ Yet, in order to invoke this type of liability, the debtor's conduct must be unconscientious, i.e. contrary to the legal standard of acting as a good host or a good businessman. ${ }^{11}$ In order to activate the mortgagee's protective rights in relation to the mortgaged asset, it is necessary to prove that the full enforcement of claim is jeopardized.

We consider that the rules regulating the obligations of a leaseholder of real estate may accordingly be used for regulating the legal position of the mortgagor (debtor). Under the Obligations Act (Art. 581), the lease-holder is bound to use the object as a good businessman or as a good host, as stipulated in the contract or in accordance with the purpose of the object. The lease-holder is liable for the damage that may occur in the course of using the leased object, particularly if the use is contrary to the contractual provisions or to the purpose of the object, regardless of the person who has been using the object, either the lease-holder himself or a person acting under their order (e.g. a subleasee). On the one hand, the mortgagee is the owner of the mortgaged property (not a lease-holder); thus, some of his authorisations are broader than those of the leaseholder; on the other hand, their position in terms of the authority to hold and use the property is similar to the position of a lease-holder (a property encumbered by mortgage). Both the mortgagor and the lease-holder are entitled to use the object not only as an authorisation but sometimes also as an obligation. "In principle, the lease-holder is not obliged to use the

\footnotetext{
${ }^{10}$ This is similar to objective liability regardless of fault (strict liability) for the compensation of damage.

${ }^{11}$ These procedural standards enable the creditor to impose various contractual obligations on the owner, such as the duty to insure the servient asset against usual risks (which is a statutory obligation envisaged in the Mortgage Act), to maintain the asset in good conditions, to preserve the purpose of the object, etc.
} 
object; it is sufficient that he pays the lease and fulfil the other obligations referred to in the lease agreement. The obligation to use the object may be envisaged in the lease agreement (e.g. the lease-holder is obliged to drive the leased car and to pass the specified number of kilometres per month); the obligation may also arise from the nature of the object (a cow must be milked otherwise it may get sick) or it may be envisaged by imperative norms" (Blagojević, Krulj, 1983:1461). We deem that this also accordingly applies to the owner of the mortgaged object; the mortgage restricts the owner's autonomy to use the object to the extent needed, to preserve the value of the mortgaged object.

When it comes to the lease agreement, "using the object as a good host means acting with due diligence of a caring and meticulous person, equal to the care given to their own belongings. It may require a higher degree of care by the lease-holder than the care they demonstrate towards their own belongings. On the other hand, the lease-holder cannot use the object contrary to its purpose. The lease-holder's obligation to use the object as a good host is limited by his obligation to use the object according to the purpose of the object; [...] both obligations have the same goal: to preserve the leased object so that the lease-holder may return it undamaged to the lessor upon the expiry of the lease period" (Blagojević i Krulj, 1983:1461). Just like the lease-holder, the mortgagor cannot change the purpose of the mortgaged property without the mortgagee's consent; the mortgagee can refuse it on justified grounds, such as the depreciation of the object's value.

2.1.3. The obligation to insure the object of mortgage. The correlation between insurance and liability will be discussed later on in this paper.

In addition to the obligation of keeping the object of the pledged right, the Act on the Right of Pledge on Movable Assets Registered in the Pledge Registry (art. 18) envisages the obligation "to keep the object of pledge right in a good condition and make the required repairs." It also provides that the pledge agreement may limit or prohibit, as well as stipulate the way in which the pledger may use the object of pledge right (art. 26). We deem that such conception of obligations is not redundant, although in mortgage relations it arises from the established standard of care about the mortgaged object.

\subsection{The Right of the Mortgagee Concerning the Preservation of the Value of the Mortgaged Object}

The creditor's right to the protection of interest in the case of depreciation of the value of the mortgaged object before the maturity of the claim should prevent the actions of the owner or the holder of the mortgaged object that depreciate its value to the extent that jeopardises the future collection of the entire claim. Since the owner of the mortgaged 
object is entitled to perform the property authorisations on the mortgaged object, it was necessary to ensure the mortgagee the legal protection aimed at precluding the damage. It entails the preventive protection against the harmful actions of the debtor, irrespective of whether there is only a risk of depreciation or whether the depreciation of the object's value has already occurred, because these rights are exercised before the maturity of the claim and the possible occurrence of damage in terms of law on contractual and non-contractual obligations. The mortgagee also has the right of access to the mortgaged estate and the right to take action to prevent the depreciation of the object's value.

2.2.1. The right of access. The right of access authorises the creditor to enter the real estate regardless of who is in it (the owner or lease-holder) for the purpose of exercising control over its maintenance or for other justified reasons. This is a statutory authorisation (Art. 17, Mortgage Act) but it may also be determined and precisely defined in an agreement, or a mortgage deed. The right of access to the real estate cannot be exercised out of business hours (from 22:00 to 07:00), or at the time of state holidays. We also deem that it should not be exercised at the time of religious holidays, if it would disturb the debtor's peace and tranquility. It is aimed at preventing the abuse of rights by the mortgagee. The owner, lease-holder and any other direct holder of the mortgaged property is obliged to cooperate with the creditor and to enable access to the mortgaged property (e.g. entry into an apartment, etc.).

The establishment of the depreciation of value or any threat of depreciation is a preliminary phase, after which the creditor may pursue some of the rights envisaged in the event of endangering the value of mortgaged objects. The depreciation of the mortgaged object is established by the competent court in non-contentious proceedings envisaged for securing evidence, upon the request of the creditor (Art. 18, para. 3, Mortgage Act). Namely, the property value should be depreciated to the extent that there is a real danger/risk that the sale of the mortgaged asset may not fully satisfy the entire claim secured by mortgage. The presence of risk concerning the creditor's interest depends on the percentage of depreciation or expected depreciation of the object's value, but also on the size of the remaining debt at the moment of the filing of the request, the mortgage rank, etc. ${ }^{12}$

\footnotetext{
${ }^{12}$ In banking business practice, when establishing the amount of credit covered by mortgage security, the accepted object of mortgage is any mortgage asset that covers the amount of the entire claim it secures (costs + interest + principal) with a maximum of $75 \%$ of the value, considering that the creditor does not want to risk the impossibility of collecting the claim after the sale of mortgaged asset (See: Lazić, 2009a:110).
} 
2.2.2. The rights concerning the prevention of value depreciation. There are two rights available to the mortgagee aimed at preventing the value depreciation of mortgaged property: the right to additional security, and the right to seek termination of detrimental actions. Although the legislator did not specify the order of actions for the protection of value depreciation, thus enabling the mortgagee to file the request that they find the most efficient, we consider that the right to seek termination of detrimental actions should be envisaged as the first request.

- The right to request a supplementary collateral of a "similar degree of security" (Art. 18, Mortgage Act)

Additional security is, practically, the right to supplement the mortgage. If the value of the mortgaged object is depreciated by the owner's or the direct holder's legal actions, and if the debtor does not provide supplementary security which is requested due to the depreciation of value of the mortgaged object, the creditor may seek premature collection ${ }^{13}$ of the entire claim.

We deem that the right to supplement the mortgage should also be envisaged in the event when the mortgaged object has a legal or material deficiency. Thus, the Croatian legislation (Art. 328, Act on Ownership and other Real Rights) envisages the corresponding application of the liability rule on defects of the objects. Anyway, the right to supplement the security instrument is envisaged in the pledge if the object has a material or legal defect and jeopardises the collection of receivables (Art. 979, Obligations Act). Considering that the pledge is an onerous contract, ${ }^{14}$ the pledger is liable for material and legal defects of the rented object.

As it is hard to provide "similar" security in practice (mortgage on another real estate), it seems that the creditor quickly proceeds to the request for premature sale and the collection of receivables. It is up to the courts to correctly apply these provisions, which may significantly endanger the debtor's and mortgagor's positions if they are not one and the same person.

- The right to seek a court order that the owner or actual holder terminate the detrimental action (Art. 19, Mortgage Act)

We consider that this should have been envisaged as the first request but, under the law, it is up to the creditor's will to decide whether

\footnotetext{
${ }^{13}$ This entails the right to premature sale and collection of receivables, not only the sale and deposition of the amount with the court until the maturity of receivables, as it is the case with pledges (Art. 982, Obligations Act).

14 "A pledge contract per se is not an onerous contract. However, given that a pledge contract is concluded for the purpose of securing claims from another contract (most commonly from a loan agreement); in that wider context, pledging things is a compensation for what the pledgor receives (money on loan)"(Blagojević, Krulj, 1983: 2079).
} 
they will file such a request beforehand or not. The request asking the court to order the owner to terminate the detrimental action is similar to the request in actio negatoria. This authorisation may be used both in cases where the value of the real estate has already been depreciated, and preventively, if there is a real danger of value depreciation. ${ }^{5}$ However, if there is only a pending risk/threat, acting upon the request of the creditor and without prior assessment of the value depreciation, the court may allow the creditor to undertake the measures necessary to avoid the depreciation of the value of the mortgaged object (Art. 19, Mortgage Act). Exceptionally, the law authorises the mortgagee to independently undertake (without seeking the court's permission) the measures for the prevention of the depreciation of the value of the mortgaged object, if there are circumstances calling for urgent action (urgency). We deem that this provision is hardly applicable in practice, considering that the object is in the possession of the creditor and that the mortgagee is hardly likely to give consent to undertaking actions without the court's decision. On the basis of a subsequent decision of the court, which would have to establish the necessity of their undertaking these actions, the costs of such actions shall be borne by the mortgagor.

With reference to comparative law, in the event where the mortgagor depreciates the value of the mortgaged object, we consider that the mortgagee should also be acknowledged the right to request the court to order the sequestration of the mortgaged real estate into the possession and management of a third party.

\section{THE RELATION BETWEEN THE INSURANCE OF THE MORTGAGED OBJECT AND CIVIL LAW LIABILITY}

The Mortgage Act (Art. 17) establishes the duty of the owner to insure the object of mortgage (mortgaged asset) against all usual risks for that type of object, prior to the conclusion of the mortgage agreement. In practice, the mortgagee conditions the mortgagor with the duty to insure the object of the mortgage and "vinculate" (link) the insurance policy to the creditor's name ${ }^{16}$ in order to ensure that they would approve the credit. We consider that this legal obligation should be stipulated in the contract, as it would enable mortgagees to use it when needed.

\footnotetext{
${ }^{15}$ The German Civil Code (Kommentar zum Bürgerlichen Gesetzbuch, §1217) guarantees the creditor the rights in case there is a risk of deterioration and in case of actual deterioration of the mortgaged real estate.

${ }^{16}$ In case of damage stemming from the insured event, the insurance amount is paid to the mortgagee, unless they agree that the amount is paid to the object owner who regularly pays the debt. If the debt is not paid regularly, the mortgagee may request the collection of debt from the insurance amount.
} 
Compulsory insurance, which is sometimes quite unnecessary, increases the costs of lending. Alternatively, this insurance issue may also be resolved by allowing the mortgagee to contract the insurance of the mortgaged object against certain harmful events in his favour but at the cost of the owner of the mortgaged object. ${ }^{17}$

The insurance rules are regulated by the Insurance Act and relevant by-laws. The statutory or contractual ${ }^{18}$ obligation to insure the mortgaged object plays a significant role in the procedure of securing the mortgagee's claim (receivables), both in relation to the depreciation of the mortgaged object value and in the event of loss of the mortgaged object. There are numerous questions on the position of the mortgagee and debtor in relation to the occurrence of the insured event.

First, we will consider the relation between insurance and civil law liability. Although initially created for different purposes, insurance and liability have eventually arrived at the same objective: to ensure the compensation for the damage caused by risks threatening a person and their property in modern life. "In a short while, both institutes have covered the same domain, but their goals are different: the goal of liability is to impose the burden of compensation on the tortfeasor, while the goal of insurance is to relieve him of this burden. Yet, both parties ultimately achieve the same goal - compensation for damage to the injured person" (Šulejić, 1992:2255).

Insurance does not abolish civil law liability. On the contrary, the existence of civil liability is a necessary precondition for the insurance to be effective. Insuring the object of mortgage is in the interest of both parties in a mortgage relationship as it simultaneously secures the tortfeasor against the burden of compensation and the injured party (the person who sustained damage) against the risk of insolvency. Thus, insurance and liability are correlated and mutually conditioned. The expansion of insurance is a consequence of the development of civil liability. Nowadays, a new form of insurance is "insurance against liability of the owner of real estate, either for the real estate itself, or for personal and cargo lifts, or for persons in his service (concierge) or third persons (thieves)" (Besson, 1992:2268).

Insurance of property (assets) certainly does not cover all kinds of damage that may jeopardise the insured asset. This only refers to the damage arising from certain dangers (risks) which are explicitly designated

\footnotetext{
${ }^{17}$ For example, Article 1285 of the Greek Civil Code entitles the mortgagee to insure the building encumbered with mortgage against fire or any other risk at the cost of the debtor; thus, the creditor can also request an deferrable payment of debt in case the debtor does not regularly pay insurance premiums.

${ }^{18}$ The Act on the Right of Pledge on Movable Property registered in the Pledge Registry (Art. 19) provides that a pledge agreement may envisage the obligation of the pledgor to insure the pledged asset, but it is not compulsory.
} 
in the conditions for specific types of property insurance. ${ }^{19}$ According to the Obligations Act (art. 898, para. 1), the insured event must refer to a future event, which is uncertain and fully independent from the contracting parties' will. The insured event covers the specific risk which is designated depending on the type of asset and the potential risk for the asset; therefore, it is specified in the policy or in the general conditions of insurance.

When an insured event occurs, the insurance amount should serve for the premature collection of claim, unless the mortgagee assesses that the recovery_of the mortgaged real estate is possible. ${ }^{20}$ These issues should be regulated in more detail by the Mortgage Act, which merely provide for the insurance obligation but leave many issues to be regulated on the basis of contractual freedom and insurance companies' rules.

The question arises whether insurance may cover the damage or loss that occurred on the grounds of fault (culpability), and what degree of fault. In property insurance agreements, insurance conditions usually do not include liability for the damage or loss caused by intentional (deliberate) act or gross negligence. However, the insurer shall be obliged to compensate any damage or loss caused by the persons whose activities are under the control of the insured person (e.g. juveniles, employees, domestic help, etc.), on any ground whatsoever, regardless of whether the damage or loss has been caused by willful misconduct or negligence (Art. 929, para. 3, Obligations Act). The Act also envisages two legal grounds for excluding the insurer's obligations and liability. Thus, the insurer's obligations are excluded in cases where the damage has been caused by war operations or rebellions, and in cases where it has been caused by the defects in the insured object (Articles 930 and 931, Obligations Act). These limitations are of dispositive nature, which means that they may be subject to negotiation and different agreement of the contracting parties.

\section{CONCLUSION}

For the owner of the mortgaged asset, the mortgage is an encumbrance on real property with postponed and potential effects. Formally, it does not deprive the owner of their property-related authorisations but, until the moment when the mortgage is extinguished, the owner is obliged to preserve the value of the mortgaged asset in order to

\footnotetext{
${ }^{19}$ The most common types of property insurance are: insurance against fire, lightning strike, explosion, thunderstorm, hail, floods and torrents, waters spillovers from sewage or water supply pipes; insurance against burglary and robbery; insurance of buildings under construction or prefabrication; insurance of crops and fruits, etc.

${ }^{20} \mathrm{We}$ consider that the court should be allowed, at the request of the owner, to approve the recovery of the object if the mortgagee unjustifiably refuses to cede the insurance amount to the debtor.
} 
ensure the exercise of the right to satisfaction. For this reason, the obligation to safeguard the mortgaged real estate in accordance with the legal standard of "a good host" for natural persons or "a good businessman" for legal persons is imposed on the mortgagor (debtor).

Concurrently, the mortgagee (creditor) is guaranteed certain rights which entail certain features of civil law liability of the debtor who has not observed the statutory or contractual obligations in terms of treatment of the mortgaged property. In order to prevent the depreciation of the mortgaged property value, the mortgagee is entitled to exercise two rights: the right to seek additional security, and the right to seek termination of detrimental actions. The legislator did not specify the order of filing requests (actions) for exercising these rights, leaving the choice of action to the mortgagee. Additional security of "similar degree of security" is, practically, the right to supplement the mortgage. If the value of the mortgaged asset is depreciated by the owner's or the direct holder's legal actions, and if the debtor does not provide additional security which is to preclude the depreciation of the mortgaged asset value, the creditor may request premature collection. We deem that the right to supplement the mortgage should also be envisaged in the event when the mortgaged object has a legal or material deficiency.

Analysing these rights and duties, we have come to the conclusion that they are a form of preventive civil law liability. As such, they preclude the damage that would be the subject matter of dispute only after the maturity of the claim.

The mortgagor's liability may also be alleviated by envisaging compulsory insurance of the mortgaged asset. This obligation is explicitly laid down by the law but, in our opinion, it should be left to the contracting parties' autonomy of will; thus, the creditor would be able to include this obligation in the contract whenever needed. As it is, the compulsory insurance increases the credit costs, which is quite unnecessary.

\section{REFERENCES}

Besson, A. [1992]. Osiguranje i građanska odgovornost [Insurance and Civil Liability], Pravni život, Beograd, no. 11-12. [pp. 2268-2283]. [This paper was published for the first time in Anali, the journal of the Faculty of Law in Belgrade, no. 3, 1958].

Blagojević, T. B. and Krulj, V. [editors] [1983]. Komentar Zakona o obligacionim odnosima [Commentary on the Obligations Act], Beograd, 1983.

Capelle, K-H. [1963]. Bürgerliches Recht Sachenrecht, Wiesbaden.

Hiber, D. and Živković, M. [2015]. Obezbeđenje i učvršćenje potraživanja [Security and Strengthening Claims], Pravni fakultet Univerziteta u Beogradu.

Kovačević Kuštrimović, R. [1992]. Zahtev da se ukloni opasnost štete [Request to Eliminate a Risk of Damage], Pravni život, Beograd, 9-10. 1225-1238.

Lazić, M. [2009a]. Prava realnog obezbeđenja [Real Security Rights], Niš, „Punta”. 
Lazić, M. [2017b]. Svojinski režim na građevinskom zemljištu i urbana komasacija [Property Law Regime on Construction Land and Urban Land Consolidation], Zbornik radova Pravnog fakulteta u Nišu, br. 76, LVI, 353-370.

Medić, D. Pravo obezbjeđenja potraživanja [The Right to Secure Claims], Banja Luka, 2013.

Nikolić, D. [1995]. Građanskopravna sankcija [Civil Law Sanctions], Univerzitet u Novom Sadu.

Radišić, J. [2014]. Obligaciono pravo [Law of Obligations], Niš, Pravni fakultet, Univerzitet u Nišu.

Josserand, L. [1992]. Evolucija odgovornosti [Evolution of Liability], Pravni život, Beograd, no. 9-10, [pp. 1164- 1178]. This text is quoted from "Branič", [1935] no. 7-8.

Simonović, I. [2013]. Restitucija i građanskopravna odgovornost zbog povrede subjektivnih prava [Restitution and Civil Liability for the Violation of Subjective Rights], Facta Universitatis, University of Niš, vol. 11, no. 2, 2013 (105-119).

Soergel, B., Siebert W. [editors], [1968]. Kommentar zum Bürgerlichen Gesetzbuch [1900], IV, Stutgart-Berlin-Keln-Mainz, [commentary to § 1147].

Stojanović: [1992]. Istorijski razvoj i ciljevi građansko-pravne odgovornosti za prouzrokovanu štetu [Historical Development and Goals of Civil Liability for Damage], Pravni život, Beograd. 9-10, 1179-1190.

Stojanović, D.; Pop-Georgiev, D. [1989]. Komentar Zakona o osnovnim svojinsko pravnim odnosima [Commentary on the Law on the Basic Ownership and Proprietary Relations], Beograd.

Šulejić, P. [1992]. Odnos osiguranja i građanskopravne odgovornosti [The Relationship between Insurance and Civil Law Liability], Pravni život, Beograd, 11-12, 22532267.

Protocol No. 4 to the Convention for the Protection of Human Rights and Fundamental Freedoms, securing certain rights and freedoms other than those already included in the Convention and in the first Protocol thereto, ETS No.046, Strasbourg, 16. IX 1963; retrieved from: https://www.echr.coe.int/Documents/Library_Collection_ P4postP11_ETS046E_ENG.pdf

Zakon o obligacionim odnosima [Obligation Relations Act, 1978], Službeni list SFRJ, br. 29/78, 39/85, 45/89; https://www.mpravde.gov.rs/files/The\%20Law\%20of\% 20Contract\%20and\%20Torts_180411.pdf

Zakon o hipoteci [Mortgage Act, 2005], Službeni glasnik Republike Srbije, br. 115/2005, 60/2015, 63/2015, 83/2015

Zakon o osiguranju [Insurance Act, 2014], Službeni glasnik RS, br. 139/2014.

Zakon o založnom pravu na pokretnim stvarima i pravima upisanim u registar [Act on the Right of Pledge on Movable Property registered in the Pledge Registry, 2003], Službeni glasnik RS, br. 57/2003, 61/2005, 64/2006 i 99/2011.

Zakon o vlasništvu i drugim stvarnim pravima Republike Hrvatske [Act on Ownership and other Real Rights of the Republic of Croatia, 1996], Narodne novine Republike Hrvatske, br. 91/96, 68/98, 137/99, 22/00, 73/00, 129/99, 114/01, 79/06, 141/06, $146 / 08,28 / 09,153 / 09,143 / 12,152 / 14$ 


\title{
ОДГОВОРНОСТ ХИПОТЕКАРНОГ ДУЖНИКА ЗА ОЧУВАЊЕ ВРЕДНОСТИ ЗАЛОЖЕНЕ НЕПОКРЕТНОСТИ
}

\author{
Милица Вучковић, Мирослав Лазић \\ Универзитет у Нишу, Правни факултет, Ниш, Србија
}

\section{Резиме}

Хипотекарни дужник, као власник предмета хипотеке, задржава сва својинска овлашћења, али добија обавезе којима се успоставља његова одговорност за очување вредности заложене ствари и чије поштовање контролише хипотекарни поверилац. Стога, власник као хипотекарни дужник не сме физички мењати предмет хипотеке без сагласности хипотекарног повериоца у писаној форми, који може да одбије захтев само из оправданих разлога; дужан је да чува и одржава предмет хипотеке као „добар домаћин” (физичка лица), односно као „добар привредник” (правна лица); одговоран је за мане ствари; обавезан је да осигура хипотековану ствар од уобичајених ризика штете итд.

Поред тога, хипотекарни поверилац добио је одређена права која може да користи ако хипотекарни дужник не поштује своје обавезе. Најважнија су право приступа и права ради предупређења смањења вредности ствари. Право приступа овлашћује повериоца на улазак у непокретности и контролу одржавања ствари од стране држаоца. Хипотекарни поверилац има два права ради предупређења смањења вредности предмета хипотеке - право на додатно обезбеђење и право на тражење престанка штетних радњи.

Посебан значај има осигурање хипотековане ствари од ризика оштећења. Осигурањем се не укида грађанскоправна одговорност хипотекарног дужника за оштећење ствари, али је обострано корисно, јер се починилац штете обезбеђује од терета накнаде под одређеним условима, а оштећени од ризика инсолвентности дужника. 